\title{
Stylistics of Nemokke in JAVAnese Wedding Ceremony in LANGKAT SUMATERA UTARA
}

\author{
Eva Serviyana ${ }^{1}$, Muhammad Natsir ${ }^{2}$, \\ SISILA FITRIANY LUBIS ${ }^{3}$ \\ ${ }^{123}$ UNIVERSITAS NEGERI MEDAN
}

\begin{abstract}
The research was about Stylistics of Nemokke in Javanese wedding ceremony in Langkat Sumatera Utara. This study was conducted by applying descriptive qualitative design. The source of data was taken from the utterances of dukun manten and activities happened in Nemokke (traditional Javanese wedding ceremony) in Langkat Sumatera Utara. The data are the transcription of the Javanese 'dukun manten' utterances recording in Javanese wedding ceremony, especially in Nemokke and activities happened in Nemokke. The technique for analyzing the data is descriptive qualitative research based on Miles \& Huberman (1984). The technique of collecting the data of this research is observation, recording and interview. The findings indicate that there were three Stylistics (Sympson, 2004) found in Javanese wedding ceremony, they were Semantics, Pragmatics and Discourse. It is suggested to the dukun manten in Javanese wedding ceremony to use Discourse to give information and to show the great meaning and audience understand.
\end{abstract}

Keywords: Stylistics, Nemokke, Javanese wedding ceremony 


\section{INTRODUCTION}

Language has very important role in human being's life. Life would be nothing without language. As human being, absolutely we need language to communicate with the others in an interaction, both spoken and written. By using language, we can express our ideas, feelings, intensions, desires and most of human's knowledge and culture stored and transmitted through language. It means that we use language as a social instrument to show our language identify in a society (Chaer, 1995: 113).

Language is absolutely for cultural development. It is a key to analyze the culture of a particular society. In fact, it is difficult for people to know and understand a certain society without knowing or mastering the language since language has a dominant part in cultures. Language enables people to store meanings and experiences and to pass this heritage on to new generation. It is conveyed through languages as a tool of communication.

North Sumatera is one of the provinces that is also known as a multicultural province which consists of some ethnics and religions. Although there are a lot of ethnics in North Sumatera, Javanese is the original citizen of this province. At least, there are 13 ethnic groups which are the original tribes and four tribes as in coming tribes. The development of social culture is relatively good and the level of people's awareness and understanding adjust to understand the pluralism, variety of cultures, mosaic of cultures and manners, and also the harmony of inter-religion follower is high. Stylistic can sit comfortably language and literature. It can contribute to the understanding of the text as cultural practice, it can work as a bridge between cultural, literary and linguistic study.

Stylistics is the study of style and the methods used in written language as a means of analyzing works of literature. Style is the use of language by a writer or a speaker in a specific way. Lawal (1997) defines style as a feature of language that deals with the choices of diction, phrases, sentences, and linguistics materials within a text. Leech (1969) states style as the way of speaking, writing or performing something.

Stylistics is the study and clarification of texts in respects to their linguistics and tonal style. As a restraint, it associates literary criticism to linguistics. It does not role as an independent area on its own, and can be applied to an emphatic of literature and journalism as well as linguistics (Mahmood and Jamil, 2015:2).

Stylistics can be described as the study of style of language usages in different contexts either linguistics or situational. It is concerned with the examination of grammar, lexis, semantics as well as phonological properties and discursive devices. Stylistics examines oral and written texts in order to determine crucial characteristics linguistics properties, structure and patterns influencing perception of the text (Mark, 2012:4)

For Javanese society especially who live in Langkat region, 'Nemokke' which becomes a symbol 
of culture of Javanese is facing a problem. This tradition in Javanese wedding ceremony almost lose in society, especially for young Javanese people. It happens because the young generation does not have passion of their own tradition and because of the influence of another tradition. For example: Javanese people who live in Langkat region where the most in habitant is Javanese, do not include 'nemokke' as their own tradition in wedding ceremony. They tend to use Javanese modern than Javanese tradition because they feel that Javanese tradition is more interesting than their own tradition. From this problem the researcher needs to make a study about Javanese tradition in wedding especially 'nemokke'.

This study is focused on studying stylistics at nemokke in Javanese wedding ceremony. Nemokke is one cultural values in Javanese wedding ceremony. To make Javanese culture exists, the researcher feels important to conduct the study on stylistics of nemokke in Javenese wedding ceremony.

From this problem the researcher needs to make a study about Javanese tradition in wedding especially 'nemokke', because by this research common people and new generation will understand the meaning of nemokke and the function of communication. The result is hoped to show the young Javanese people that Javanese tradition is also interesting to do when they will have a wedding ceremony.

\section{REVIEW OF LITERATURE}

\subsection{Definition of Stylistics}

The concept of style has variety of meanings in and outside the literary text. It is commonly an issue that we use the term "style" without knowing its meaning. Stylistics is the study of the devices in languages such as rhetorical terms and syntactical devices that are taken to produce expressive or literary style. Stylistics is therefore a study which conjoins both literary criticism on the one hand and linguistics on the other as its morphological structure suggests: the "style" is relating to literary criticism and the "istics" is to linguistics (Bilal \& Cheema, 2012:2).

"Style" is a word derived from Latin word "elocution" which means style and means "lexis" in Greek. Style is a broader term. It has several meanings in and outside of the literary text. A particular procedure by which something is done, a manner or a way is style. Broadly, appearance of everything is style. The way of doing something or the way of living is also style. Style is also related to a personality of a person. A style reflects the thoughts of a person's mind. It describes the way of person's speaking and writing (Aslam, et.al, 2014). The term style is used occasionally in literary criticism and it is defined according to one's own field of study. So, there are many interpretations of word style. According to Thorn Borrow (2000: 3) stylistics is a branch of linguistics which studies the characteristics of situationally-distinction uses of language, with particular reference to literary language and tries to establish principles cap able of accounting for the particular choices made by individuals and social groups in their use of language. 
According to Simpson (2004:20), stylistics is a method of textual interpretation in which primacy of place is assigned to language. Stylistics is interested in language as a function of texts in context and it acknowledges that utterances (literary or otherwise) are produced in a time, (lace and in a cultural and cognitive context. These 'extra-linguistics' parameters are inextricably tied up with the way a text 'means'. The more complete and context-sensitive the description of language, then the fuller the stylistic analysis that accrues.

Stylistics is sometimes called literary stylistics or linguistics stylistics (Wales, 1995:438). It is called literary because it tends to focus on literary text meanwhile it is called linguistics stylistics because its model is taken from language. Thus, it can be said that stylistics is mediation between two disciplines, linguistics and literature. Furthermore, according to Wellek and Warren (1965), linguistics theories play an important part in the history of poetry, with its stress on denotation, connotation, imagery, tone, has influenced English poetry.

Stylistics analysis in linguistics refers to the identification of usage patterns in speech and writing. Stylistics analysis in literary studies is usually made for the purpose of commenting on quality and meaning in a text. Stylistics, in other words is the study of style used in literary and verbal language and the effect writer or speaker wishes to communicate to the reader or hearer. It attempts to establish principles capable of explaining the particular choices made by individual and social groups in their use of language, such as socialization, the production or reception of meaning, literary criticism and critical discourse analysis (Khattak, et.al, 2012).

\subsection{Level of Stylistic Analysis}

\section{Semantics}

Semantics is the study of meaning in language. Meaning may be so vague, insubstantial and elusive that it may be impossible to come to a clear, concrete, or tangible conclusions about it. By careful thought about the language you speak and the way it is used, definite conclusions can be arrived at concerning meaning.

Semantics it is the study of literal, decontextualized, grammatical meaning. Semantics is concerned with conceptual meaning related to words. Semantics does not focuses on the context, rather it deals with the meaning according to Grammar \& vocabulary. The focus is only on the general rules used for a languages.

2. Pragmatics

Pragmatics is the study of aspects of the use of meaning and language that depend on the speaker, receiver and other features of the speech context.

\section{Discourse}

In this area, for instance the interest lies in information processing (theme-rheme) and to what extent a text is coherent and what cohesive devices were used to achieve the particular level of coherence of the text. 
This study was conducted by using descriptive qualitative design, which had the natural setting as the direct source of data (Bogdan, 1992:29). Thus, interpretations on the collected data are the primary concern of the study. Creswell (1994:148) describes the idea of qualitative research is to purposefully select dukun manten (people, documents, or visual materials) that will be the best answer to the research questions.

\section{FINDINGS AND DISCUSSIONS}

\section{Findings}

After analyzing Stylistics of nemokke in Javanese wedding ceremony in Langkat uttered by dukun manten and activities happened in nemokke, the whole data were converted or summarized into the finding of the study. It is aimed in order to be structural and more concise. They are presented, as follows:

1. The findings showed that the Stylistics of nemokke in Javanese wedding ceremony uttered by dukun manten contained to show information of a big honor and appreciation to the bride's side and groom's side, and the audiences. Dukun manten says greeting as the polite expression and to form of verbal communication. Dukun manten shows her smiling face and with optimism. The dukun manten used the sentences in discourse also to give the great respect to each other.

2. Based on Sympson's theory (2004) about Stylistics divided into three, namely:

a. Semantics in nemokke of Javanese traditional wedding ceremony commonly had the meaning of sentences uttered by dukun manten.

b. Pragmatics in this nemokke focus on dukun manten used of language.

c. Discourse in this nemokke, the dukun manten used the sentences in discourse also to give the great respect to each other, not only for the bride's side and groom's side, but to other audience in the event.

3. The material elements daun sirih and kain panjang as complementary thing supported the nemokke. In now a days the use of sirih and kain panjang only just a symbol. In this ceremony it symbolizes betel leaf is believed to have the power to ward off bad disorders. Characteristics of betel leaf is the unbroken segment, but the circle become a symbol and hope that the bride and groom's marriage will also be lasting and unbroken. Symbolizes kain panjang (sindur) is a rectangular cloth that resembles a shawl.

Nemokke is held in the morning, sometimes in the afternoon. Depending on the situation and conditions. Stylistics applied in Nemokke realized in Javanese wedding ceremony in Langkat, because we can understand what the dukun manten say and understand what Nemokke is goals.

\section{Discussions}

In Javanese wedding ceremony, there are some utterances which are uttered by the dukun manten. The dukun manten tend to say the information about each side clearly to show their respect and honor, so the dukun manten deliver the sentences in Discourse. The dukun manten use the Discourse to show the honor to the other side and to the audience.

From the findings it is well that the purpose of the Nemokke in Javanese traditional wedding 
ceremony are accompanied by the level of Stylistics, semantics, pragmatics and discourse. So, in this discussion it can be seen that the theory worked in reality.

\section{CONCLUSIONS AND SUGGESTIONS}

\section{Conclusions}

The study concerned with stylistics of Nemokke in Javanese wedding ceremony, which is uttered by the dukun manten. Based on the analysis, conclusions are stated as the following:

1. There were three categories of Stylistics which are found in Nemokke event in Javanese wedding ceremony. They are Semantics, pragmatics and discourse. The most dominant level of stylistics which is used in Nemokke event in Javanese wedding ceremony are discourse.

2. All level of stylistics that applied were semantics, pragmatics and discourse. Semantics refers to meaning of nemokke the uttered by dukun manten. Pragmatics of the use of meaning and language that depend on the dukun manten the speech context in nemokke, and Discourse was how the situation and the way of performance in that event.

\section{Suggestion}

It is suggested to those, who concerned with Javanese culture to learn Javanese wedding ceremony. It is because Javanese wedding ceremony will affect to the words selection used during the event takes place. In addition the special suggestion offered to the following:

1. It is suggested to the other researchers, this research can be used as a valuable reference in investigating the same subject.

2. It is suggested to the dukun manten in Javanese wedding ceremony to use the informative statement to give information and to show the great honor and respect to the audience.

3. It is suggested to the young generation this research common people and new generation will understand the meaning of nemokke.

4. It is suggested to the Javanese people to learn more about Javanese culture especially Javanese wedding ceremony and to socialize Javanese culture to the other culture that Javanese culture is also interesting to study.

\section{REFERENCES}


Abcarian, R. 1982.Instructor's Manual to Accompany Literature, the Human experience. New York: Monarh Press.

Abrams, M. H. 1999. A Glossary of Literary Terms. Boston: Heinle and Heinle. Aslam, Mukhtar, and Sarfaraz. 2014. Stylistics Analysis of the Poem "Bereft" By

Robert Frost. European Journal of Research and Reflection in Arts and Humanities. Vol. 2.No.1.

Bailey, K. 1994. Methods of Social Research.New York: The Free Press.

Batool, Naheed, Khalid, Khan, and Muhammad. 2015. Stylistics Analysis of AlfreadTennison's Poem Tears. International Journal of Multidisciplinary Research and Development.Vol.3 :194-196.

Best, J.W. 1982.Research in Educational. New Delhi: Prentice-Hall. Bilal and Cheema. 2012. Stylistic Analysis of Wordsworth's Poem: Early Spring. British Journal of Humanities and Social Sciences. Vol. 5 (2)

Bogdan, C.R and Biklen, S.K 1992. Qualitative Research for Education: An Introduction Theory and Methods, $2^{\text {nd }}$ edition. Needham Heights, M.A:llyn and Bacon

Chaer, Abdul. 1995. PengantarSemantikBahasa Indonesia. Jakarta. RinekaCipta. Creswell, J. W. 1994. Research Design: Qualitative Approaches. Thousand Oaks: Sage.

Davidson, Donald. 1978. "What Metaphors Mean." Reprinted in Inquiries Into Truth and Interpretation.Oxford University Press.

Galperin, I.R. 1977. Stylistics.Moscow.

Ilka, T. 1987. PoetickSlovnk. Tatran; Bratislava.

Khan, A.B. Sumera, M.A. Ahmed and Batool. 2014. Stylistic Analysis of William Blake's Poem: "night”. Journal of ELT ad Applied Linguistics.Vol.2.No. 4.

Khan and Jabeen. 2015. Stylistics Analysis Of The Poem 'To Autumn' By Autumn’ By John Keats. International Journal of Academic Research and Reflection.Vol.3.No.1.

Khattak, M.I. Mehnaz. Khattak, M.A. 2012. The Role of Stylistics in 
Interpreting Literature.City University Research Journal.Vol.2.No. 1.

Leech, G. 1969. A Linguistic Guide to English Poetry. London: Longman.

Lawal, R. A. 1997. Pragmatics in Stylistics: A Speech Act Analysis Soyinka's Thelephone Conversation. In R. A. Lawal (Ed.) Stylistics in theory and practice, Ilorin: Paragon Books.

Mahmood, Rabia. And Jamil, Anila. 2015. Stylistics Analysis Of Holly Thursday I By William Blake. International Journal of English Language and Linguistics Research.Vol.3. No. 6: 46-52.

Malmkjar, K. and Anderson. J. M. 1991. The Linguistics Encyclopedia.London: Roudledge.

Mark, Mary. 2012. Stylistic Analysis of Ola Rotimi's Hopes of the Living Dead. An International Journal of Language, Literature and Gender Studies.Vol. 1. No. 2 :96-110.

Miles M. B. \&Huberman, M. 1984. Qualitative data analysis: A sourcebook of New Method. Beverly Hills: Sage.

Perrine, L. 1969. Sound and Sense. New York: Harcourt, Brace\&Worldinc. Ramadhani, Ika. 2012. Politeness Strategies used in Javanese Wedding Ceremony.

Unpublished Thesis. Medan: English Applied Linguistic Study Program, State University of Medan.

Reaske. C. 1996. How to Analyze Drama.New York: Monarh Press.

Sembiring, Grace. 2013. Stylistic Devices In Political Texts of the daily Analisa. Unpublished Thesis: Post Graduate Program. State University of Medan.

Sharndama, Emmanuel C and Suleiman, Jamila B.A. 2013. An Analysis of Figurative languages in Two Selected Traditional Funeral songs of the Kilba people of Adamawa State. International Journal of English and Literature. Vol.4. No.4: 166-173. 